DE DE GRUYTER

OPEN

DOI 10.2478/pesd-2014-0030

PESD, VOL. 8, no. 2, 2014

\title{
THE STUDY OF STAGES AND OPERATIONS INVOLVED IN THE PRESERVATION AND RESTORATION OF TWO XIX-th CENTURY ICONS, ON WOODEN SUPPORT
}

\author{
Munteanu Marius ${ }^{1}$, Ion Sandu ${ }^{1,2}$, Ioana Huțanu ${ }^{1}$, Liliana Nica ${ }^{1}$ \\ Key words: icons, stopping xylophagous attack, consolidations, reintegration, \\ restoration
}

\begin{abstract}
The paper presents the stages and the operations involved in the preservation and restoration of two icons on wooden support, from the XIX-th century, which are part of the heritage of the "Sfinții Arhangheli Mihail and Gavriil" church, from Galați. The two icon have inventory numbers as part of the collection as followed: 112 for the first icon and 113 for the second one. Both icons have the same theme, "The Grieving Mother from Rohia" and are made by anonymous painters in egg tempera, on lime wooden support, without ground. Being part of the same collection, they were deposited in the same place and as a direct consequence, they suffer from similar deteriorations and degradations that affect both the support and the painting layer. Both panels are attacked by xylophagous insects and the painting layer has detachments, gaps, cracks, clogged dirt and a cracked and degraded varnish layer. Ten samples taken from the already detached areas were analyzed by optical microscope, SEM-EDX and micro-FTIR. Based on the chemical elements identified in the EDX spectrums, the pigments used to create the painting layer are: ultramarine natural blue Na8-10A16Si6O24S2-4, carbon black, earth green, $\mathrm{K}[(\mathrm{Al}, \mathrm{FeIII}),(\mathrm{FeII}, \mathrm{Mg})](\mathrm{AlSi} 3, \mathrm{Si} 4) \mathrm{O} 10(\mathrm{OH}) 2$, ocher $(\mathrm{FeO})$, burned or natural umber $\mathrm{Fe} 2 \mathrm{O} 3 \cdot \mathrm{H} 2 \mathrm{O}+\mathrm{MnO} 2 \cdot \mathrm{n} \mathrm{H} 2 \mathrm{O}+\mathrm{Al} 2 \mathrm{O} 3$, lead white $(2 \mathrm{PbCO} 3 \cdot \mathrm{Pb}(\mathrm{OH}) 2)$ and yellow iron oxide $(\mathrm{Fe} 2 \mathrm{O} 3 \cdot 4 \mathrm{H} 2 \mathrm{O})$. It was also determined that the gold leaf usually used in byzantine icons was replaced in the case of both icons: the icon number 112 has silver leaf covered with varnish, while the halo of the icon number 113 was created with yellow metallic pigments (realgar or orpigment). The pigments were also identified by determining specific peaks in micro-FTIR spectrums. For natural ultramarine blue the peaks between $628-724$
\end{abstract}

1 „Al. I. Cuza” University of Iasi, ARHEOINVEST Platform, Blvd. Carol I 11, 700506, Iasi, Romania

${ }^{2}$ Romanian Inventors Forum, Str Sf. Petru Movila 3, L11, III/3, 700089, Iasi, Romania 
$\mathrm{cm}-1$ were assigned; the peaks in the interval $795-887 \mathrm{~cm}-1$ confirm the presence of carbonates (calcium and lead based). The earth green pigment (aluminum silicates) had the peaks between $1464-1599$, while the carbon black pigment was confirmed by the peaks in the interval $921-1060 \mathrm{~cm}-1$. After the pigments and the materials used by the author were identified, the restoration process begun with the following stages: consolidation of the painting layer (fish glue $8 \%$ and japanese paper), stopping the xylophagous attack (encapsulation with nitrogen), consolidation of the wood supports (colophon and wax, 1:1), cleaning the painting layer (ethylic alcohol and distilled water, 1:1), filling the gaps and reintegrating the fillings in tratteggio, all followed by the process of varnishing the two icons.

\section{Introduction}

The two icons part of "Sfinții Mihail and Gavriil" church collection, from Moscu village, Galati, are very similar. Both icons have the same theme, and that is "The Grieving Mother from Rohia". The structural composition is the same for both icons, the only significant difference being the shape of the lower scenes of the icons: the icon number 112 has square lower scenes while the second icon with inventory number 113, has round medallions. Both icons are painted in neobyzantine style using egg tempera and the colors used are the same, the general chromatic impression offered by the two art pieces being quite similar: the cloak of the Virgin Mary is dark, surrounded by a green ocher background that becomes darker to the edges of the panels.

Although they have these similarities and are painted in the same period of time, the two icons are done by two different authors, as proven by the different technique used in painting the face of the Mother and the different writing style [1].
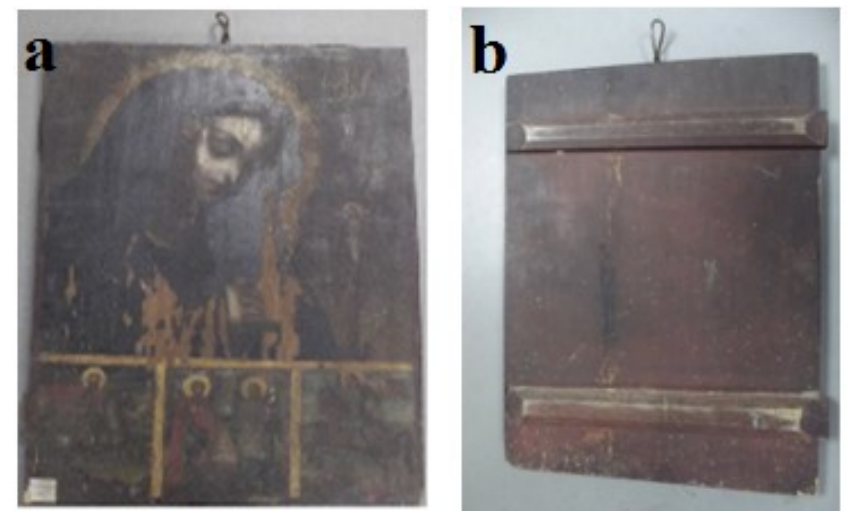

Fig. 1. The Grieving Mother from Rohia nr. 112:a - the front of the icon; $b$ - the back of the icon 

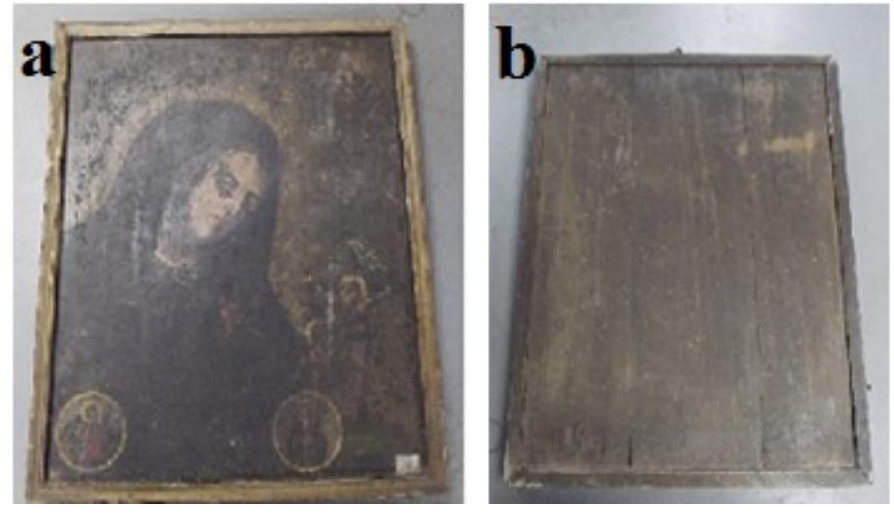

Fig. 2. The Grieving Mother from Rohia nr. 113: a - the front of the icon; $b$ - the back of the icon

\section{Storage environment and the state of conservation}

The environment were the two icons were kept has a significant importance on their state of conservation. The high values of humidity $(65 \%-85 \%)$ and temperature $\left(18^{\circ}-\right.$ $25^{\circ} \mathrm{C}$ ) allowed for the xylophagous attack to begin. Also the fluctuations of these two climate factors have subjected the wood supports and the painting layers to tensions. These tensions were caused by the continuous exchange of water between the wood supports and the environment, in order to obtain a fluid balance. The repeated tensions lead to crack in the mass of the wood and in the painting layer [2-4].

\subsection{The state of conservation}

Because the icons were kept in the same improper environment regarding the stability of atmospheric factors (temperature, humidity), the two icons suffer from a series of similar deteriorations and degradations that require establishing a restoration and preservation protocol.

The two icons are made on lime wooden panels: the one for the icon number 112 is made out of two boards that are kept together by two sparrow crossbeams, from side to side of the panel and the panel of the icon number 113 is made out of three boards, locked tight by a frame. Both the systems that keep the panels together and the panels themselves, have suffered, beside from the xylophagous attack, from a series of deteriorations and degradations. For example, the deteriorations are: boards distancing from each other (fig. 3), cracks, fly holes (fig. 4) support missing due to improper handling and structural weakness caused by insect attack (fig. 5) and the degradations are clogged dirt and wood changing color.

The two painting layers also suffer from deteriorations: cracks, gaps, detachments (fig. 7), fly holes and degradations like clogged dirt (fig. 6), browned varnish and blisters [6-10]. 

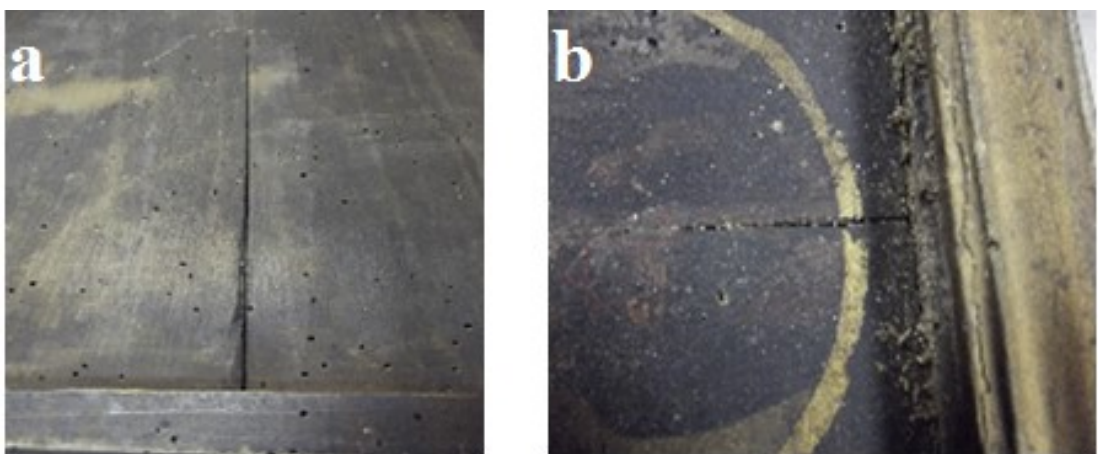

Fig. 3. The Grieving Mother from Rohia nr.113:distance between the boards of the panel: $\mathrm{a}$ - back, b - front;
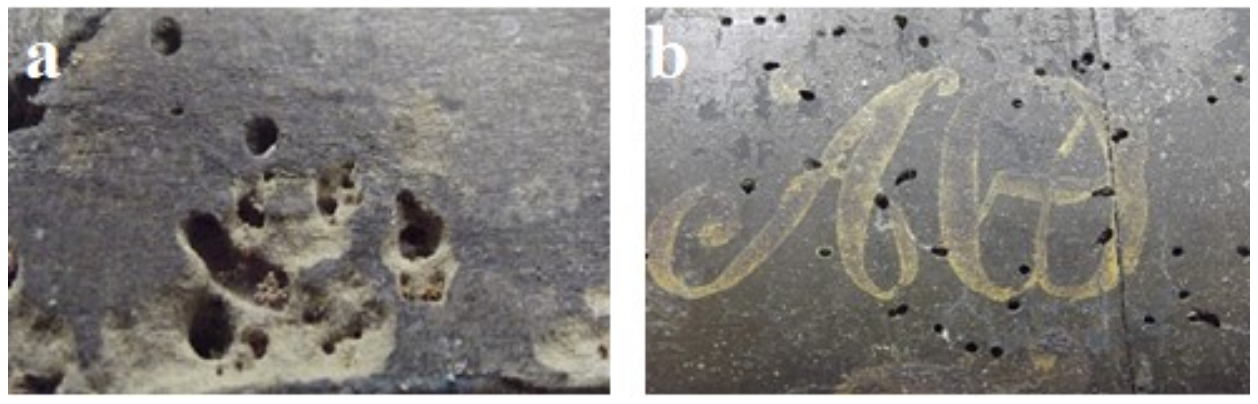

Fig. 4. The Grieving Mother from Rohia: a - xylophagous atac on the back of the icon nr. 112 ; b - xylophagous atac on the back of the icon nr. 113;
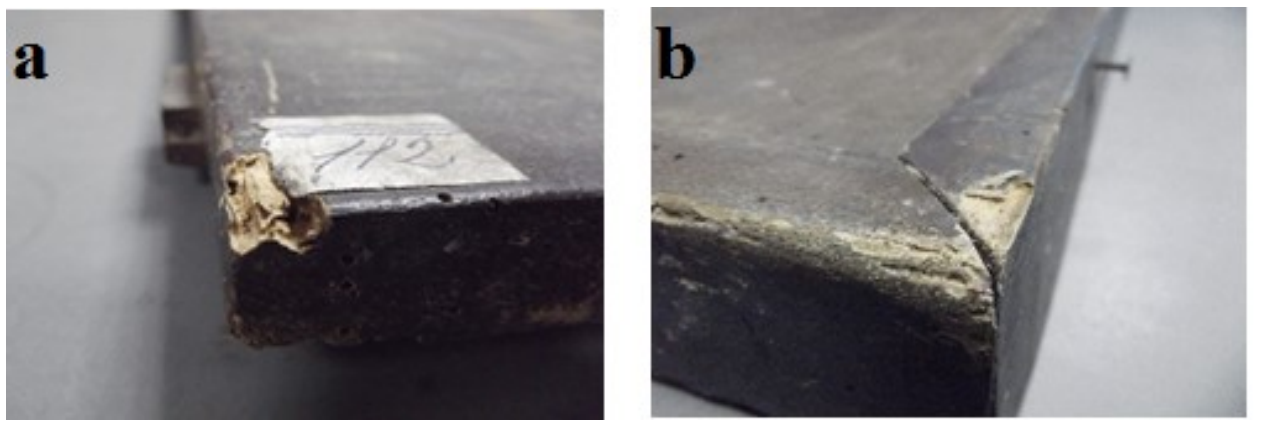

Fig. 5. The Grieving Mother from Rohia: a - support missing on the icon nr. 112; b support missing on the icon nr.113 

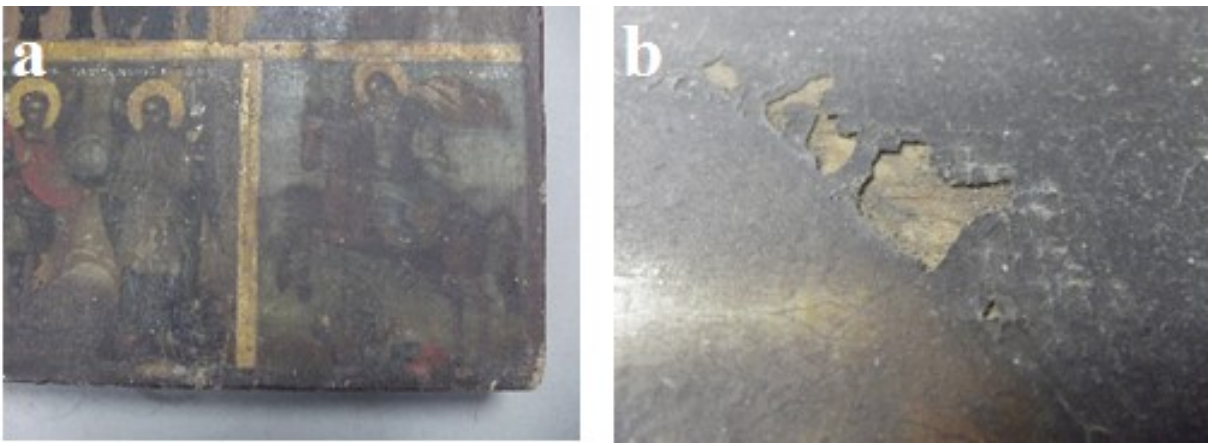

Fig. 6. The Grieving Mother from Rohia: a - dirt on the icon nr. 112; $\mathrm{b}$ - dirt on the icon nr. 113
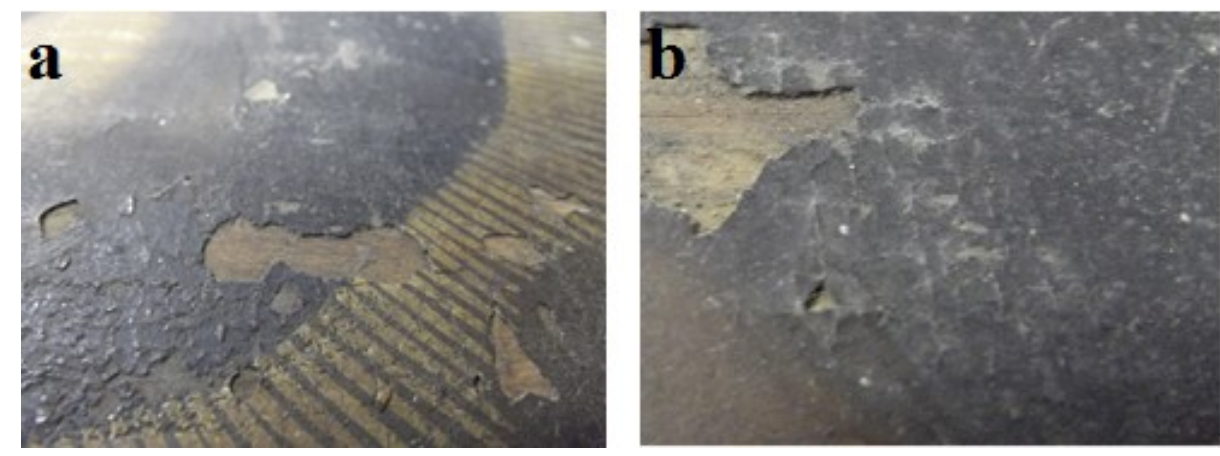

Fig. 7. The Grieving Mother from Rohia: a - cracks of the painting layer on the icon nr. $112 ; \mathrm{b}$ - cracks of the painting layer on the icon nr. 113
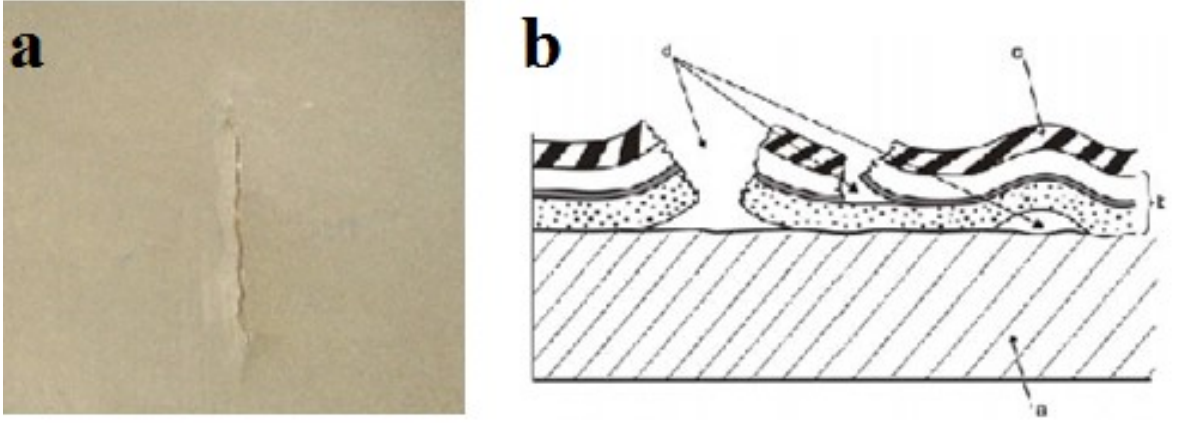

Fig. 8. The Grieving Mother from Rohia: a - detachments on the icon nr. 113b stratigraphic structural drawing $(\mathrm{a}$ - wooden support, $\mathrm{b}$ - painting layer, $\mathrm{c}-\operatorname{dirt}, \mathrm{d}-$ detachments;) 


\section{Experimental part}

Five samples from each painting layer of the two icons were taken as shown in the figures $9 a$ and $b$.
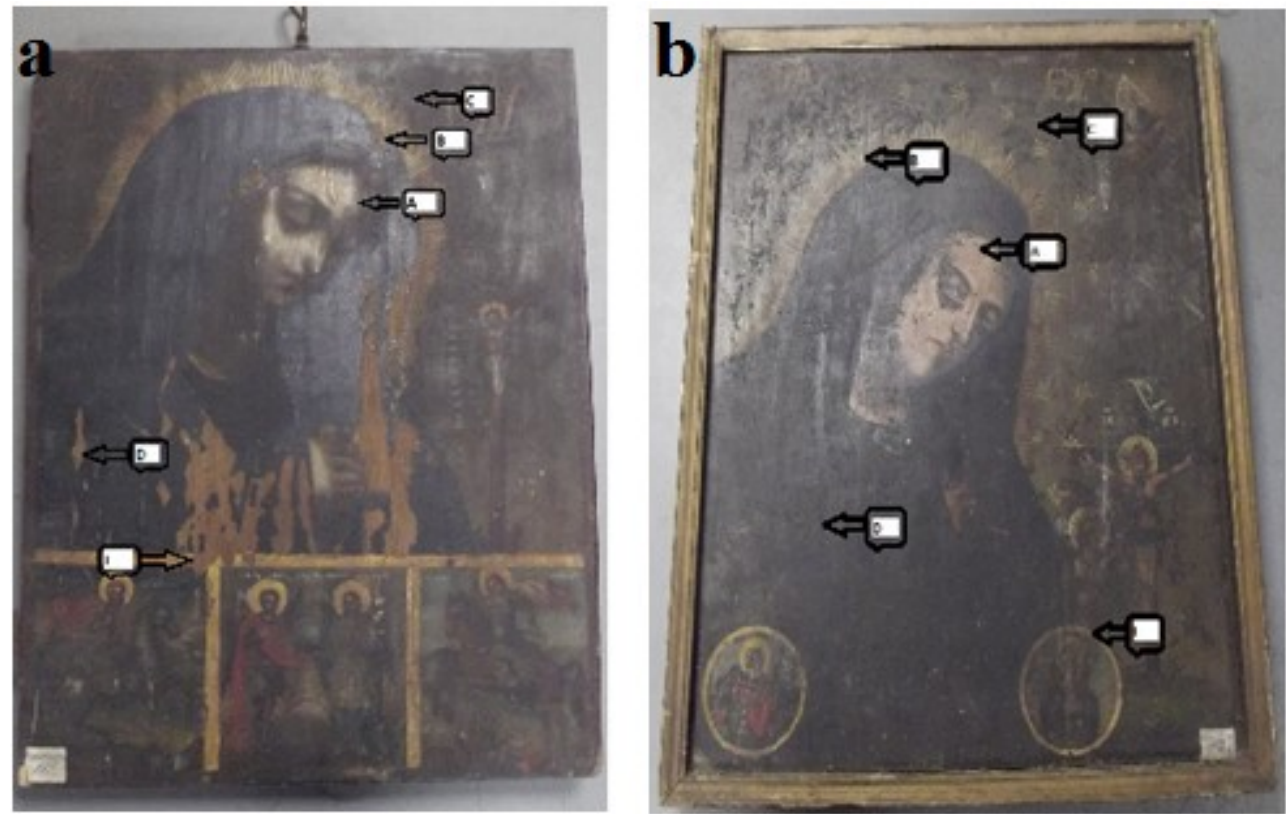

Fig. 9. Areas from where the samples were taken: a- Icon number 112 a) - face; b - halo; c - background; d - cloak; e - lower scene border; b) - Icon number 113 a - face; b - halo; c - background; d - cloak; e - lower scene border

The following instruments were used in analysis: CARL ZEISS AXIO IMAGER A1m microscope, with an attached AXIOCAM camera, the samples being enhanced between $50 \mathrm{X}$ and 500X.in order to identify chemical elements, the samples were analyzed with an electronic microscope, model VEGS II LSH, made by TESCAN, in Check Republic, coupled with an QUANTAX QX2 X-ray spectroscope, made by BRULER/PROENTEC from Germany. The Micro-FTIR spectrums were recorded with a FT-IR spectroscope coupled with a Hyperion 1000 microscope, both from Brüker Optic Equipment, Germania [11-13].

Based on the optical microscope analysis of the 10 samples taken from the two samples it was determined that the colors used to create the background and the cloaks are similar: a combination of blue, black and green for cloaks and green, ochre, umber and black for the background (fig. 11. c-h). The face is made in both cases with a mixture of white, ochre and green and black in shadow (fig. 11. a-b). The last two samples analyzed were those taken from the lower scenes borders. 

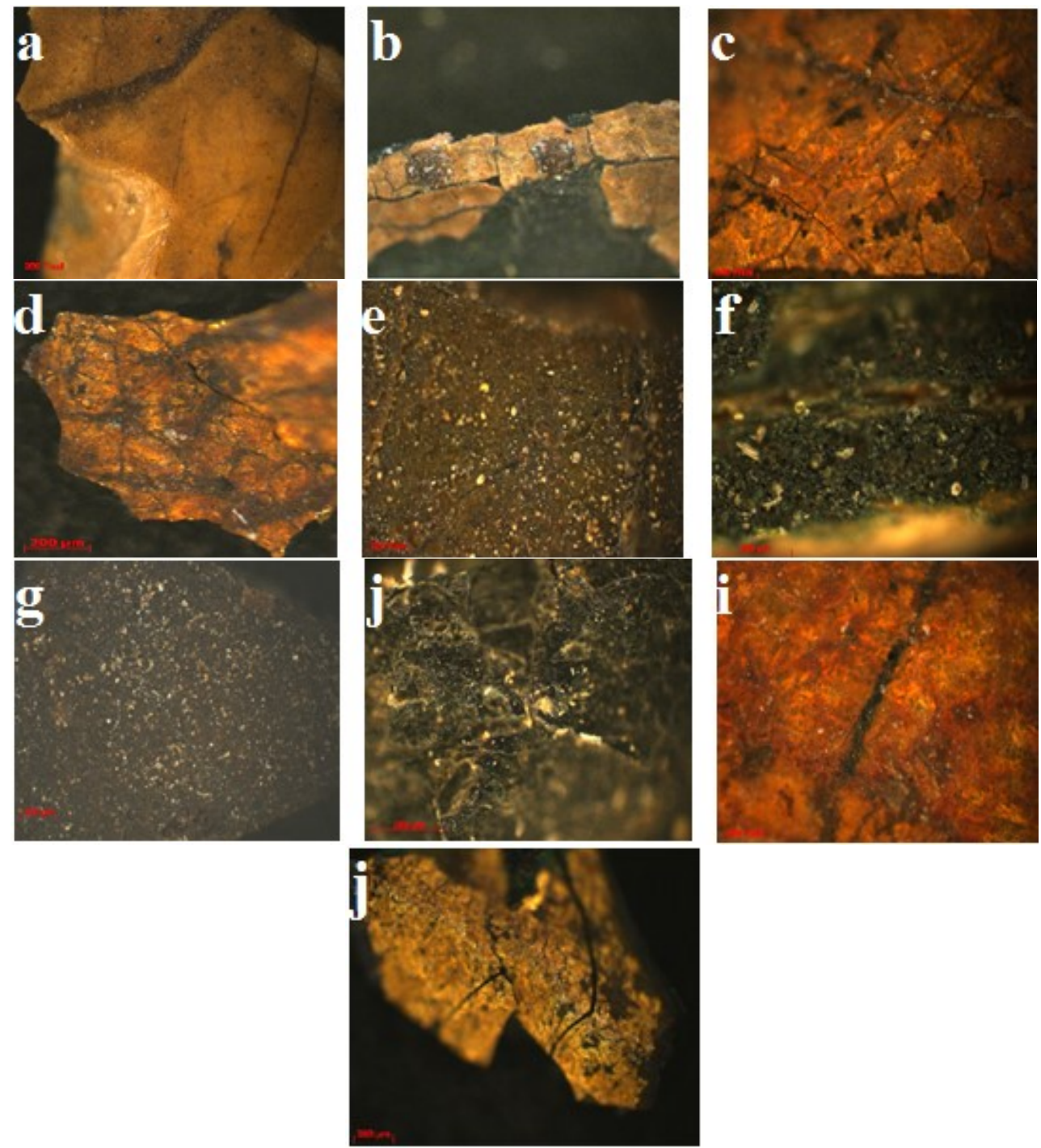

Fig. 11. Images obtained with the OM for the samples taken from different areas of the two icons: $\mathrm{a}$ - face from the icon $\mathrm{nr} .112 ; \mathrm{b}$ - face from the icon $\mathrm{nr} .113$; c -halo from the icon nr. 112; d - halo from the icon nr. 113; e - background from the icon nr. 112; f background from the icon $\mathrm{nr} .113 ; \mathrm{g}$-cloak from the icon $\mathrm{nr} .112 ; \mathrm{h}$ - cloak from the icon nr. 113; i - borders from the icon nr. 112; j - borders from the icon nr. 113; 
The sample taken from from the icon number 112 shows a metallic yellow leaf (fig. 11i). The sample taken from the border of the icon number 113 presents a yellow metallic pigment (fig. 11j). All samples show significant traces of clogged dirt and cracked varnish.

The SEM-EDX analysis was done on the same 10 sample taken from the two painting layers (fig. 12-18). One of the first conclusions was the lack of ground and canvas, which was a decisive factor in the evolution of the deteriorations and the degradations of the two icons. It was also established that the green pigment used in the painting of the backgrounds is earth green $\mathrm{K}[(\mathrm{Al}, \mathrm{FeIII}),(\mathrm{FeII}, \mathrm{Mg})]\left(\mathrm{AlSi}_{3}, \mathrm{Si}_{4}\right) \mathrm{O}_{10}(\mathrm{OH})_{2}$, combined with carbon black, ocher $(\mathrm{FeO})$ and burned or natural umber $\mathrm{Fe}_{2} \mathrm{O}_{3} \cdot \mathrm{H}_{2} \mathrm{O}+\mathrm{MnO}_{2} \cdot \mathrm{n}_{2} \mathrm{O}+\mathrm{Al}_{2} \mathrm{O}_{3}$ (fig. 14-15). The cloaks were done with a mixture of ultramarine natural blue $\mathrm{Na}_{8-10} \mathrm{Al}_{6} \mathrm{Si}_{6} \mathrm{O}_{24} \mathrm{~S}_{2-}$ 4, mixed with carbon black and earth green (fig. 12-13)[6]. The face of The Virgin Mary on both icons was done with lead white $\left(2 \mathrm{PbCO}_{3} \cdot \mathrm{Pb}(\mathrm{OH})_{2}\right)$ and yellow iron oxide $\left(\mathrm{Fe}_{2} \mathrm{O}_{3} \cdot 4 \mathrm{H}_{2} \mathrm{O}\right)$ or mars yellow (fig. 16-17). The SEM-EDX analysis of the sample taken from the halo of the icon number 112 revealed that the metallic leaf used is silver, not gold leaf as originally believed (Fig. 18). In the case of the icon number 113, the yellow metallic pigment used was based on $\mathrm{S}, \mathrm{Cr}$ şi $\mathrm{Pb}$ (realgar or orpigment, mixed with other earth colors) (Fig. 19) [14-16].

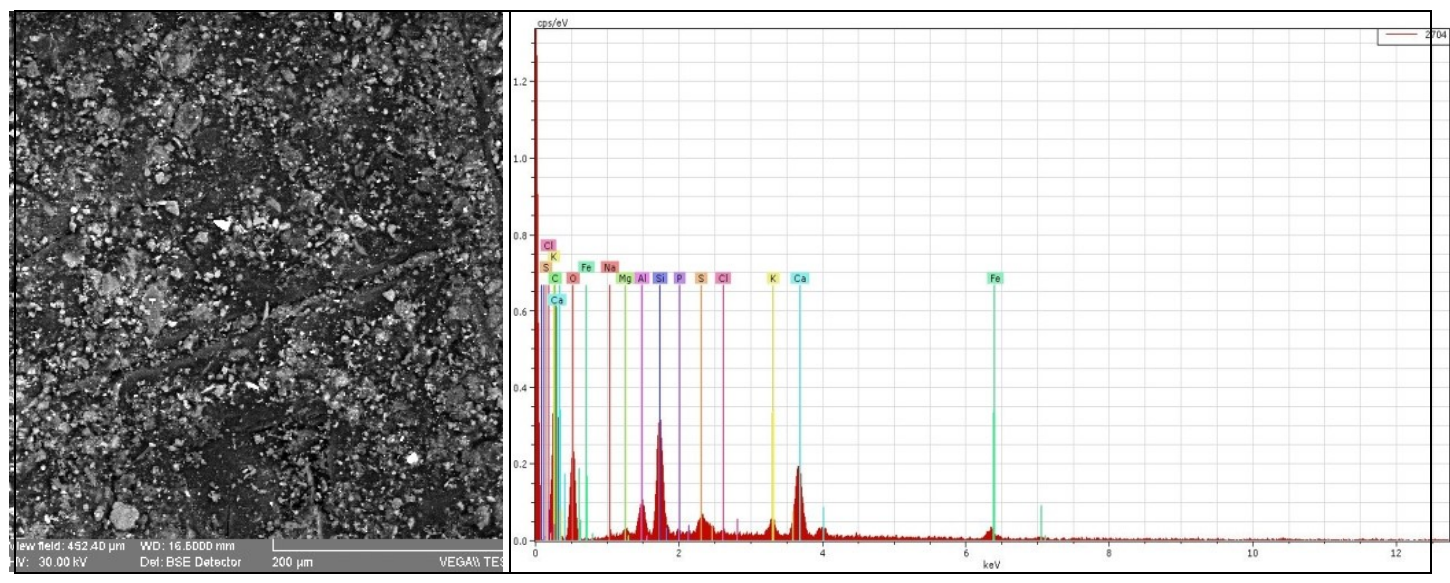

Fig. 12. SEM microphotography, BSE, 500X, EDX spectrum of the sample taken from the cloak of the icon nr. 112 


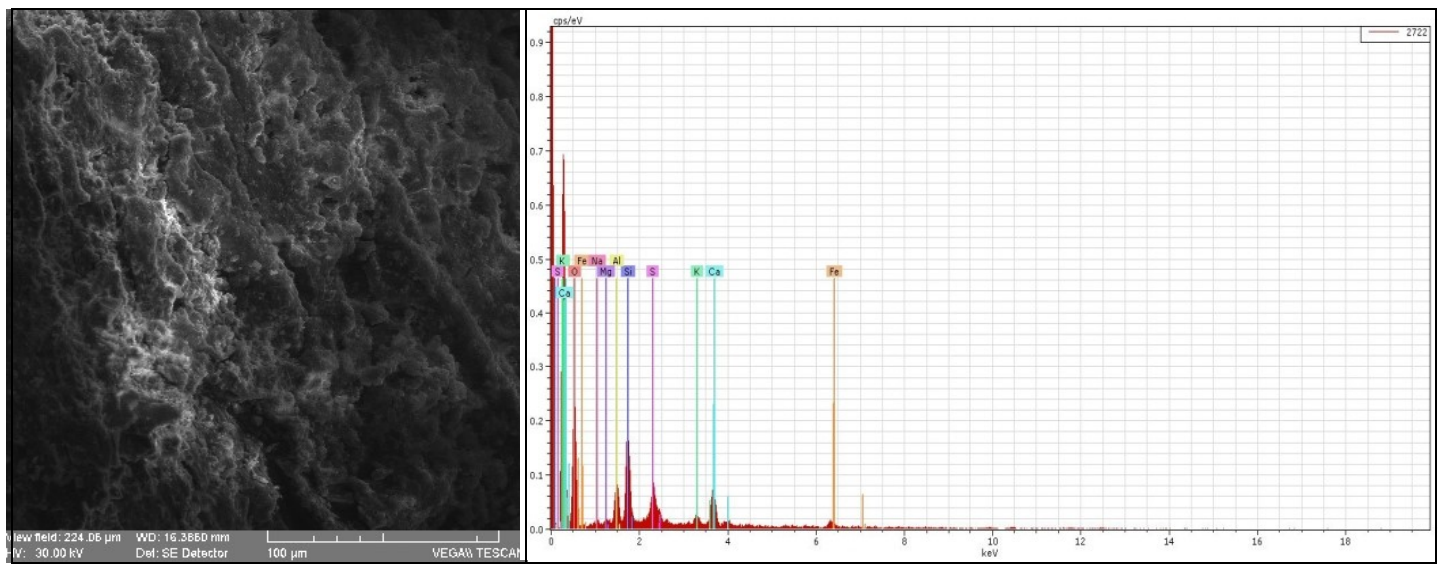

Fig. 13. SEM microphotography, SE, 1000X, EDX spectrum of the sample taken from the cloak of the icon nr. 113

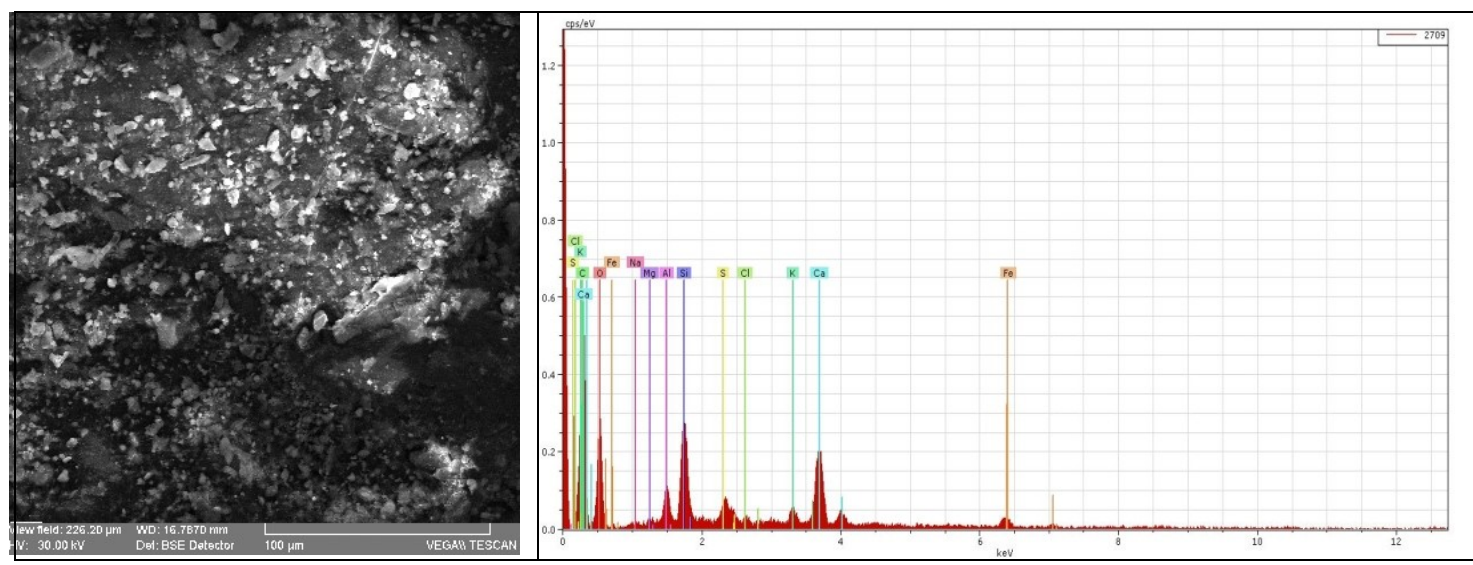

Fig. 14. SEM microphotography, BSE, 1000X, EDX spectrum of the sample taken from the background of the icon nr. 112 


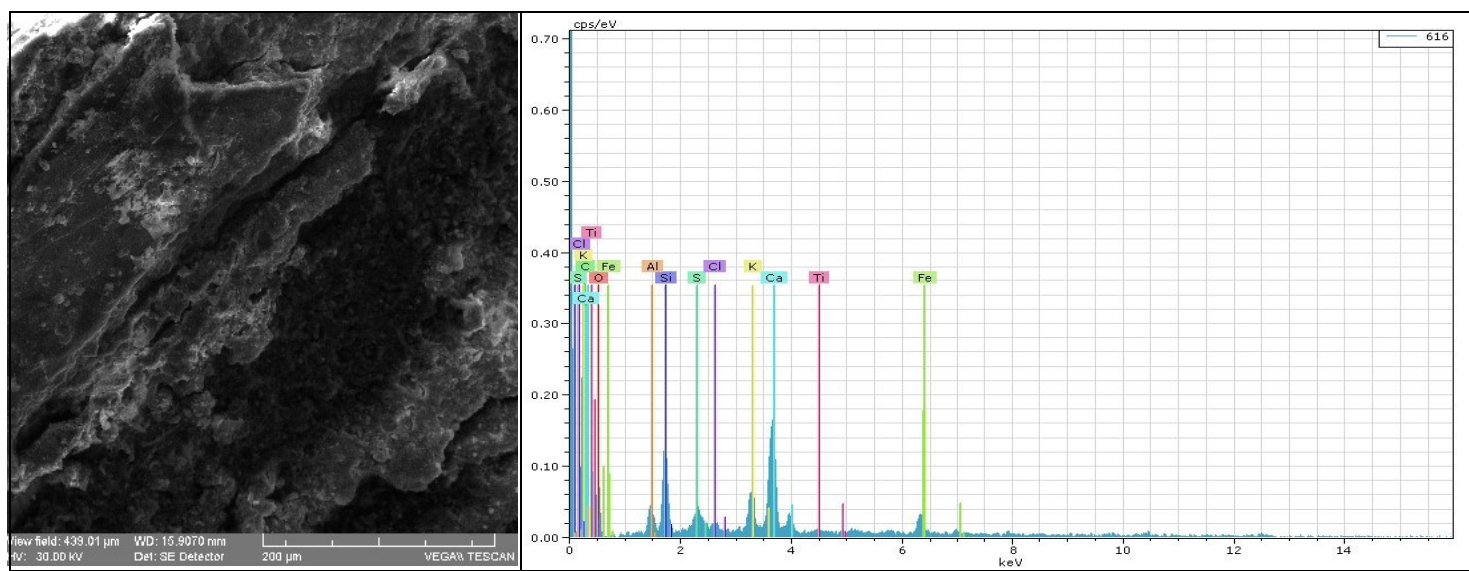

Fig. 15. SEM microphotography, SE, 500X, EDX spectrum of the sample taken from the background of the icon nr. 113
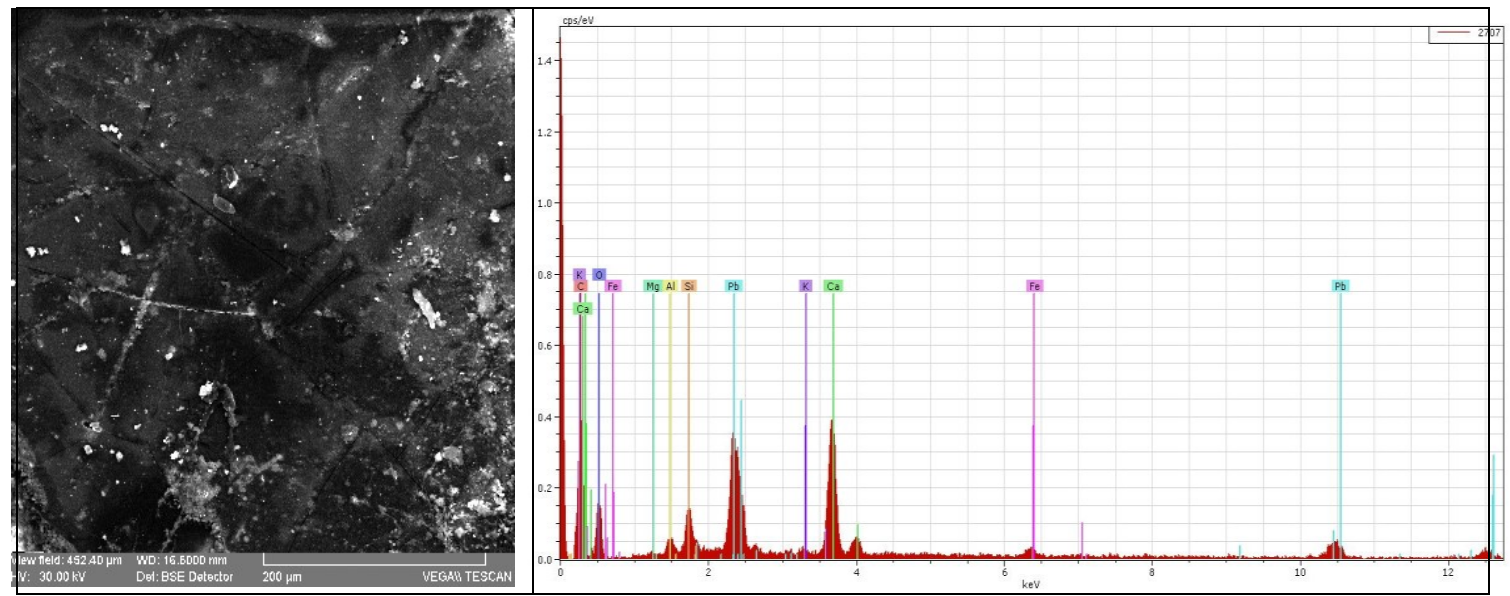

Fig. 16. SEM microphotography, BSE, 500X, EDX spectrum of the sample takenfrom the face of the icon $\mathrm{nr} .112$ 


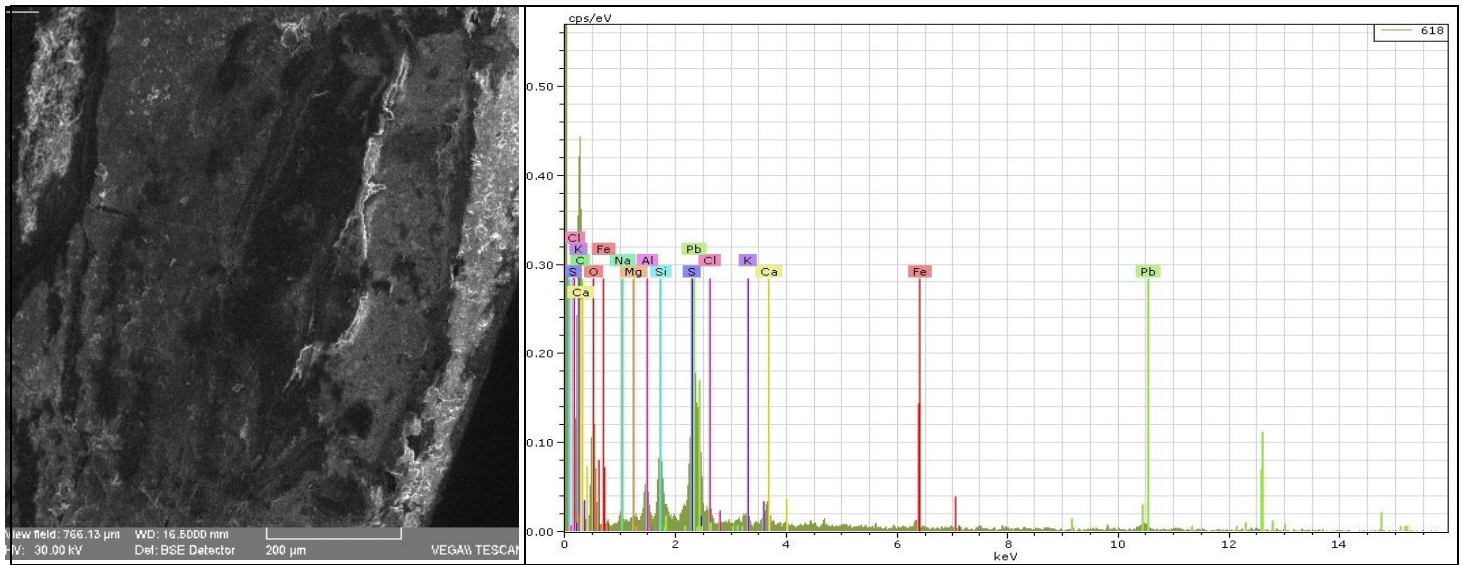

Fig. 17. SEM microphotography, BSE, 300X, EDX spectrum of the sample taken from the face of the icon nr. 113

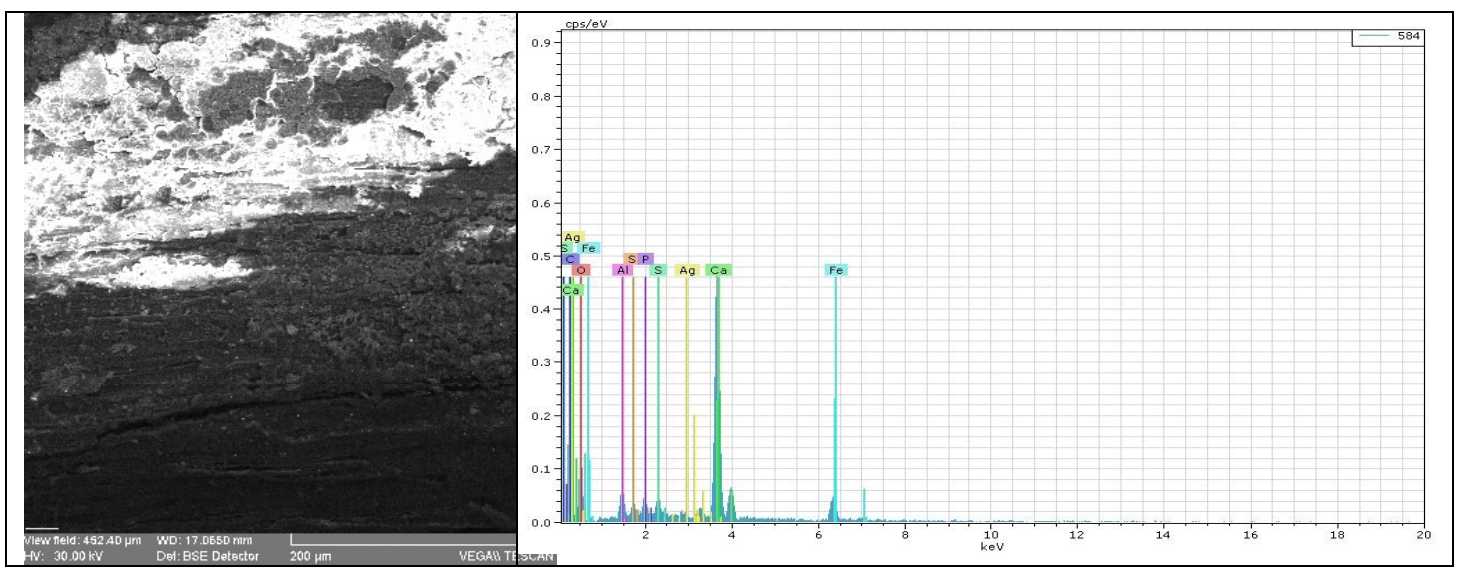

Fig. 18. SEM microphotography, BSE, 1500X, EDX spectrum of the sample taken from the halo of the icon nr. 112 


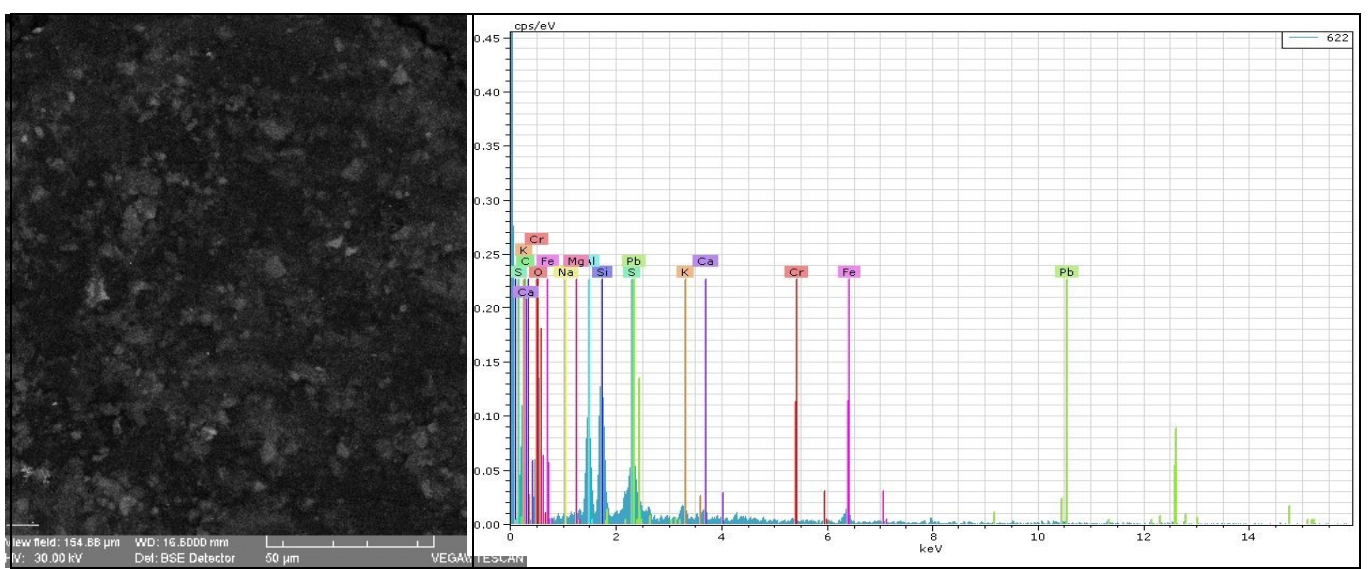

Fig. 19. SEM microphotography, BSE, 500X, EDX spectrum of the sample taken from the halo of the icon $\mathrm{nr} .113$

Tab. 1. SEM-EDX results

\begin{tabular}{|c|c|c|c|c|}
\hline Nr. & Sample & $\begin{array}{c}\text { Chemical elements } \\
\text { identified }\end{array}$ & $\begin{array}{c}\text { Concentration } \\
\text { (wt.-\%) }\end{array}$ & Determined pigments \\
\hline \multirow[t]{12}{*}{1} & \multirow{12}{*}{$\begin{array}{l}\text { Cloak of the } \\
\text { icon number } \\
112\end{array}$} & Carbon & 16.38881 & \multirow{12}{*}{$\begin{array}{c}\text { ultramarine natural blue } \mathrm{Na}_{8-} \\
{ }_{10} \mathrm{Al}_{6} \mathrm{Si}_{6} \mathrm{O}_{24} \mathrm{~S}_{2-4} \text { mixed with carbon } \\
\text { black and earth green, } \\
\mathrm{K}[(\mathrm{Al}, \mathrm{FeIII}),(\mathrm{FeII}, \mathrm{Mg})]\left(\mathrm{AlSi}_{3}, \mathrm{Si}_{4}\right) \mathrm{O}_{10}( \\
\mathrm{OH})_{2} .\end{array}$} \\
\hline & & Silicon & 6.172971 & \\
\hline & & Calcium & 3.941729 & \\
\hline & & Aluminium & 2.267281 & \\
\hline & & Sulfur & 1.386985 & \\
\hline & & Iron & 1.512083 & \\
\hline & & Potassium & 1.228655 & \\
\hline & & Chlorine & 0.230147 & \\
\hline & & Magnesium & 0.681442 & \\
\hline & & Sodium & 0.642462 & \\
\hline & & Phosphorus & 0.252832 & \\
\hline & & Oxygen & 65.2926 & \\
\hline \multirow[t]{9}{*}{2} & \multirow{9}{*}{$\begin{array}{l}\text { Cloak of the } \\
\text { icon number } \\
113\end{array}$} & Carbon & 14.12818 & \multirow{9}{*}{$\begin{array}{c}\text { ultramarine natural blue } \mathrm{Na}_{8-} \\
{ }_{10} \mathrm{Al}_{6} \mathrm{Si}_{6} \mathrm{O}_{24} \mathrm{~S}_{2-4} \text {, mixed with carbon } \\
\text { black and earth green, } \\
\mathrm{K}[(\mathrm{Al}, \mathrm{FeIII}),(\mathrm{FeII}, \mathrm{Mg})]\left(\mathrm{AlSi}_{3}, \mathrm{Si}_{4}\right) \mathrm{O}_{10}( \\
\mathrm{OH})_{2} .\end{array}$} \\
\hline & & Silicon & 6.149608 & \\
\hline & & Calcium & 2.667325 & \\
\hline & & Sulfur & 3.429675 & \\
\hline & & Aluminium & 3.294889 & \\
\hline & & Iron & 1.285284 & \\
\hline & & Potassium & 1.279955 & \\
\hline & & Magnesium & 0.828494 & \\
\hline & & Sodium & 1.508789 & \\
\hline
\end{tabular}




\begin{tabular}{|c|c|c|c|c|}
\hline & & Oxygen & 65.42581 & \\
\hline \multirow[t]{11}{*}{3} & \multirow{11}{*}{\begin{tabular}{|} 
Background of \\
he icon number \\
112
\end{tabular}} & Carbon & 15.0315 & \multirow{11}{*}{$\begin{array}{c}\text { earth green } \\
\mathrm{K}[(\mathrm{Al}, \mathrm{FeIII}),(\mathrm{FeII}, \mathrm{Mg})]\left(\mathrm{AlSi}_{3}, \mathrm{Si}_{4}\right) \mathrm{O}_{10}( \\
\mathrm{OH})_{2} \text {, carbon black, ocher }(\mathrm{FeO}), \\
\text { burned or natural umber } \mathrm{Fe}_{2} \mathrm{O}_{3} \cdot \mathrm{H}_{2} \mathrm{O}+ \\
\mathrm{MnO}_{2} \cdot \mathrm{n} \mathrm{H}_{2} \mathrm{O}+\mathrm{Al}_{2} \mathrm{O}_{3}\end{array}$} \\
\hline & & Silicon & 5.320449 & \\
\hline & & Calcium & 4.118289 & \\
\hline & & Aluminium & 2.137188 & \\
\hline & & Sulfur & 1.470609 & \\
\hline & & Iron & 1.172684 & \\
\hline & & Potassium & 0.753333 & \\
\hline & & Magnesium & 0.52451 & \\
\hline & & Sodium & 0.650922 & \\
\hline & & Chlorine & 0.261094 & \\
\hline & & Oxygen & 68.55742 & \\
\hline \multirow[t]{10}{*}{4} & \multirow{10}{*}{\begin{tabular}{|} 
Background of \\
he icon number \\
113
\end{tabular}} & Carbon & 19.01557 & \multirow{10}{*}{$\begin{array}{c}\text { earth green } \\
\mathrm{K}[(\mathrm{Al}, \mathrm{FeIII}),(\mathrm{FeII}, \mathrm{Mg})]\left(\mathrm{AlSi}_{3}, \mathrm{Si}_{4}\right) \mathrm{O}_{10}( \\
\mathrm{OH})_{2}, \text { carbon black, ocher }(\mathrm{FeO}), \\
\text { burned or natural umber } \mathrm{Fe}_{2} \mathrm{O}_{3} \cdot \mathrm{H}_{2} \mathrm{O}+ \\
\mathrm{MnO}_{2} \cdot \mathrm{n} \mathrm{H}_{2} \mathrm{O}+\mathrm{Al}_{2} \mathrm{O}_{3}\end{array}$} \\
\hline & & Silicon & 2.560286 & \\
\hline & & Calcium & 3.81289 & \\
\hline & & Potassium & 1.923999 & \\
\hline & & Aluminium & 0.952073 & \\
\hline & & Sulfur & 0.742888 & \\
\hline & & Chlorine & 0.174678 & \\
\hline & & Titanium & 0.393397 & \\
\hline & & Iron & 1.316699 & \\
\hline & & Oxygen & 69.1059 & \\
\hline \multirow[t]{10}{*}{5} & \multirow{10}{*}{$\begin{array}{c}\text { Face of the icon } \\
\text { number } 112\end{array}$} & Carbon & 12.18437 & \multirow{10}{*}{$\begin{array}{l}\text { lead white }\left(2 \mathrm{PbCO}_{3} \cdot \mathrm{Pb}(\mathrm{OH})_{2}\right) \text { and } \\
\text { yellow iron oxide }\left(\mathrm{Fe}_{2} \mathrm{O}_{3} \cdot 4 \mathrm{H}_{2} \mathrm{O}\right)\end{array}$} \\
\hline & & Calcium & 10.09271 & \\
\hline & & Iron & 1.549817 & \\
\hline & & Aluminium & 1.081189 & \\
\hline & & Lead & 22.09014 & \\
\hline & & Silicon & 2.510692 & \\
\hline & & Magnesium & 0.308795 & \\
\hline & & Potassium & 1.535387 & \\
\hline & & Oxygen & 69.08678 & \\
\hline & & & 12.18437 & \\
\hline \multirow[t]{9}{*}{6} & \multirow{9}{*}{$\begin{array}{c}\text { Face of the icon } \\
\text { number } 113\end{array}$} & Carbon & 10.13674 & \multirow{9}{*}{$\begin{array}{l}\text { lead white }\left(2 \mathrm{PbCO}_{3} \cdot \mathrm{Pb}(\mathrm{OH})_{2}\right) \text { and } \\
\text { yellow iron oxide }\left(\mathrm{Fe}_{2} \mathrm{O}_{3} \cdot 4 \mathrm{H}_{2} \mathrm{O}\right)\end{array}$} \\
\hline & & Calcium & 8.55483 & \\
\hline & & Iron & 1.89711 & \\
\hline & & Lead & 21.52378 & \\
\hline & & Aluminium & 0.95278 & \\
\hline & & Magnesium & 0.48537 & \\
\hline & & Silicon & 2.28903 & \\
\hline & & Potassium & 1.57688 & \\
\hline & & Oxygen & 52.58347 & \\
\hline
\end{tabular}




\begin{tabular}{|c|c|c|c|c|}
\hline \multirow[t]{9}{*}{7} & Halo of the icon & Calcium & 17.72147 & \multirow{9}{*}{$\begin{array}{c}\text { metallic silver leaf, covered with } \\
\text { colophon }\end{array}$} \\
\hline & \multirow[t]{8}{*}{ number 112} & Carbon & 12.01592 & \\
\hline & & Iron & 4.579725 & \\
\hline & & Aluminium & 1.703742 & \\
\hline & & Silver & 1.18262 & \\
\hline & & Silicon & 0.490081 & \\
\hline & & Sulfur & 0.753321 & \\
\hline & & Phosphorus & 0.71379 & \\
\hline & & Oxygen & 74.078 & \\
\hline \multirow[t]{12}{*}{8} & \multirow{12}{*}{$\begin{array}{c}\text { Halo of the icon } \\
\text { number } 113\end{array}$} & Carbon & 11.3623 & \multirow{12}{*}{$\begin{array}{c}\text { yellow metallic pigment based on } \mathrm{S}, \\
\mathrm{Cr} \text { şi } \mathrm{Pb} \text { (realgar or orpigment) mixed } \\
\text { with other earth colors. }\end{array}$} \\
\hline & & Silicon & 10.86487 & \\
\hline & & Aluminium & 8.959683 & \\
\hline & & Iron & 2.591668 & \\
\hline & & Sodium & 1.848374 & \\
\hline & & Potassium & 1.477127 & \\
\hline & & Sulfur & 3.961862 & \\
\hline & & Calcium & 1.075373 & \\
\hline & & Magnesium & 1.474293 & \\
\hline & & Lead & 18.87234 & \\
\hline & & Chromium & 0.887938 & \\
\hline & & Oxygen & 36.62217 & \\
\hline
\end{tabular}

The results obtained after OM and SEM-EDX were confirmed through microFTIR analysis, specific peaks being identifyed for several pigments and material used, as followed:

$\checkmark$ natural ultramarin blue pigment $628,655,699$ and $735 \mathrm{~cm}^{-1}$ in the micro FTIR spectrum of the icon number 112 (fig. 20a) and 639,694 and $724 \mathrm{~cm}^{-1}$, in the spectrum of the icon number 113 (fig. 20b).

$\checkmark$ For carbonates (calcium and lead based) 795,829 and $886 \mathrm{~cm}^{-1}$ (fig. 20a), 816 and $883 \mathrm{~cm}^{-1}$ (fig. 20b), 849 and $887 \mathrm{~cm}^{-1}$ (fig. 21a), 812 and $845 \mathrm{~cm}^{-1}$ (fig. 22a), 801 and $868 \mathrm{~cm}^{-1}$ (fig. 22b).

$\checkmark$ Earth green was identified by peaks specific to alumino silicates: 1473 and $1581 \mathrm{~cm}^{-1}$ (fig. 20a), 1464, 1523 and $1599 \mathrm{~cm}^{-1}$ (fig. 20b), 1469 and $1599 \mathrm{~cm}^{-1}$ (fig. 21a), $1467 \mathrm{~cm}^{-1}$ (fig. 21b), 1468 and $1595 \mathrm{~cm}^{-1}$ (fig. 22a), 1467 and $1570 \mathrm{~cm}^{-1}$ (fig. $22 b)$.

The carbon black was identified by used peaks specific for tar: $1056 \mathrm{~cm}^{-1}$ (fig. 20a), 925 and $1060 \mathrm{~cm}^{-1}$ (fig. 20b), 921 and $1052 \mathrm{~cm}^{-1}$ (fig. 21a), $925 \mathrm{~cm}^{-1}$ (fig. 22a), 936 and $1015 \mathrm{~cm}^{-1}$ (fig. 22b). The presence of carbon black in the sample from the face of the icon number 112 is explained by the fact that the sample was taken from the shadow. 
For amidic group from peptides, the amino group and the carbonic group from amino acids: 1581 and $1680 \mathrm{~cm}^{-1}$ (fig. 20a), 1523 and $1737 \mathrm{~cm}^{-1}$ (fig. $20 \mathrm{~b}$ ), $1599,1678,1741 \mathrm{~cm}^{-1}$ (fig. 21a), 1678 and $1739 \mathrm{~cm}^{-1}$ (fig. 21b), 1595 and $1724 \mathrm{~cm}^{-1}$ (fig. 22a), 1644 and $1736 \mathrm{~cm}^{-1}$ (fig. 22b).

The colophon, with resin acids as a main component, the identification was done by the peaks specific for carboxylic, aldehidic and hidroxilic groups, as followed: in figure 20a, 1056 and $2012 \mathrm{~cm}^{-1}$, in figure $20 \mathrm{~b}, 1060$ and $2093 \mathrm{~cm}^{-1}$, in figure $21 \mathrm{a}, 2131 \mathrm{~cm}^{-1}$, in figure $21 \mathrm{~b}, 1052$ and $2093 \mathrm{~cm}^{-1}$, in figure $22 \mathrm{a}, 2090 \mathrm{~cm}^{-1}$ and in figure $22 \mathrm{~b}, 1061$ and $2099 \mathrm{~cm}^{-1}$.

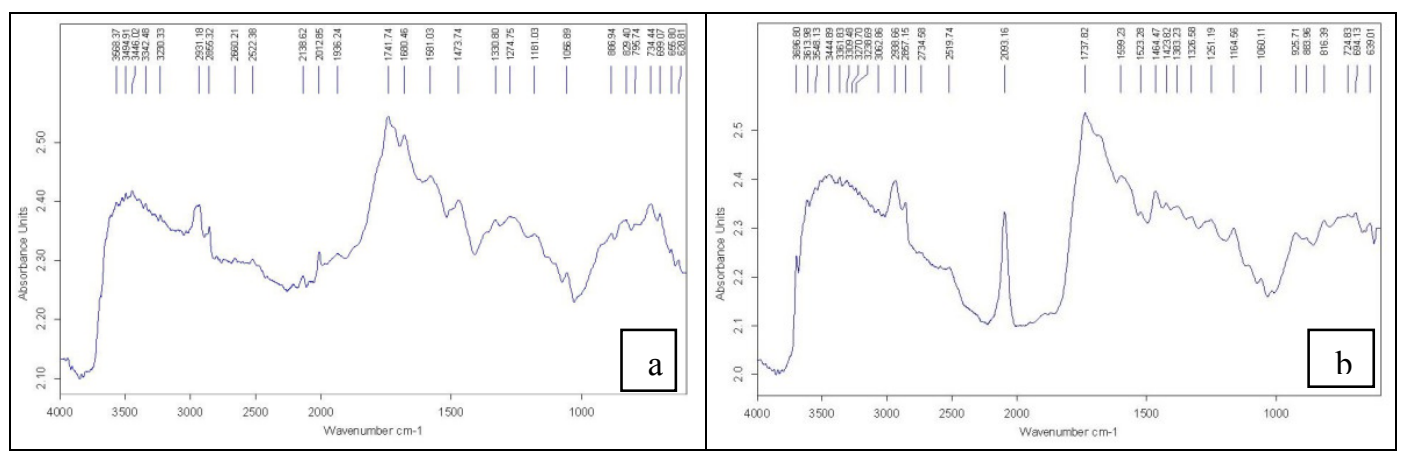

Fig. 20. Cloak micro-FTIR spectrum: a) icon number 112; b) icon number 113

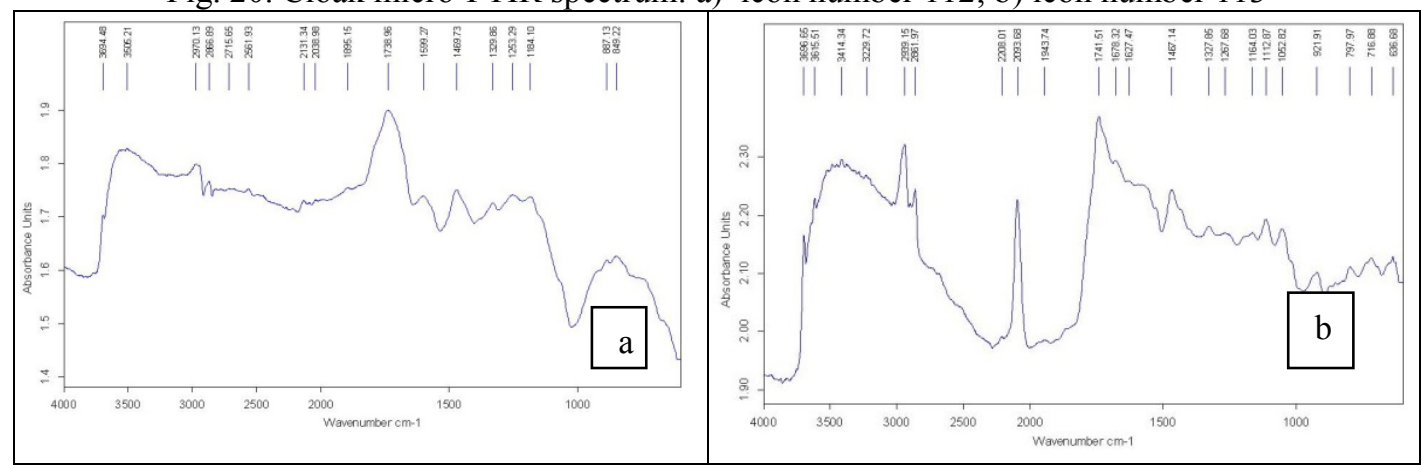

Fig. 21. Face micro-FTIR spectrum: a) icon number 112; b) icon number 113 


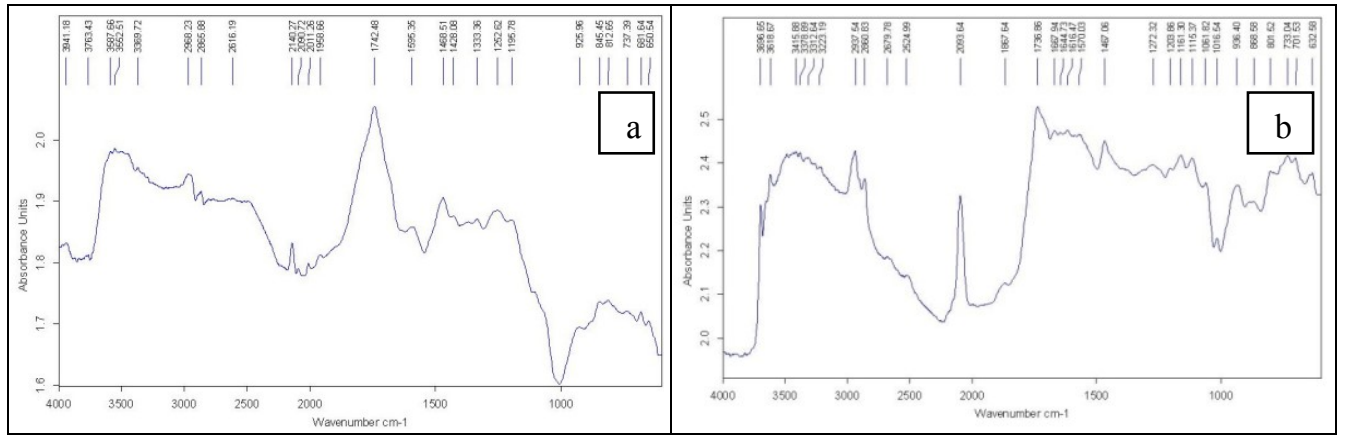

Fig. 22. Background micro-FTIR spectrum:a) icon number 112 ; b) icon number 113

Tab. 2. Micro-FTIR results

\begin{tabular}{|c|c|c|c|c|c|c|c|}
\hline Nr. & $\begin{array}{c}\text { Identified } \\
\text { pigments }\end{array}$ & $\begin{array}{c}\text { Peaks in sample } \\
\text { from the cloak of } \\
\text { icon number } 112 \\
\qquad\left(\mathrm{~cm}^{-1}\right)\end{array}$ & $\begin{array}{c}\text { Peaks in sample } \\
\text { from the cloak of } \\
\text { icon number } 113 \\
\left(\mathrm{~cm}^{-1}\right)\end{array}$ & $\begin{array}{l}\text { Peaks in sample from the } \\
\text { face of the icon number } \\
112\left(\mathrm{~cm}^{-1}\right)\end{array}$ & \begin{tabular}{|c|} 
Peaks in sample \\
from the face of \\
the icon number \\
$113\left(\mathrm{~cm}^{-1}\right)$
\end{tabular} & 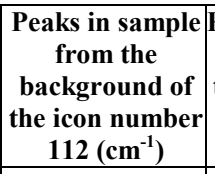 & $\begin{array}{c}\text { Peaks in sample from } \\
\text { the background of } \\
\text { the icon number } 113 \\
\left(\mathrm{~cm}^{-1}\right)\end{array}$ \\
\hline 1 & $\begin{array}{c}\text { Natural } \\
\text { ultramarin blue } \\
\text { pigment }\end{array}$ & $628,655,699,735$ & 639,694724 & - & - & \begin{tabular}{|l|}
- \\
\end{tabular} & - \\
\hline 2 & $\begin{array}{c}\text { Carbonates } \\
\text { (calcium and lead } \\
\text { based) }\end{array}$ & $795,829,886$ & 816,883 & 849,887 & - & 812,845 & 801,868 \\
\hline 3 & $\begin{array}{l}\text { Alumino silicates } \\
\text { - earth green }\end{array}$ & 1473,1581 & $1464,1523,1599$ & 1469,1599 & 1467 & 1468,1595 & 1570 \\
\hline 4 & Carbon black & 1056 & 925,1060 & 921,1052 & - & 925 & 936,1015 \\
\hline 5 & $\begin{array}{c}\text { Amidic group } \\
\text { from peptides, th } \\
\text { amino group and } \\
\text { the carbonic } \\
\text { group from amin } \\
\text { acids }\end{array}$ & 1581,1680 & 1523,1737 & $1599,1678,1741$ & 1678,1739 & 1595,1724 & 1644,1736 \\
\hline 6 & $\begin{array}{l}\text { Colophon, with } \\
\text { resin acids as a } \\
\text { main component }\end{array}$ & 1056,2012 & 1060,2093 & 2131 & 1052,2093 & 2090 & 1061,2099 \\
\hline
\end{tabular}

\section{Stages of the restoration processes}

The first stage of the restoration process is the consolidation of the painting layers in order to prevent the loss of other painting pieces already detached. The consolidation was done by fixing the painting layer with fish glue $(8 \%)$ and japanese paper.

The stopping of the xylophagous attack was done by encapsulating the two icons in a polyethylene bag for a period of 14 days. In the bag the value of oxygen 
was reduced below $0.1 \%$ by replacing it with nitrogen (fig. 23-24). The nitrogen atmosphere in the bag was done with the help of a hose and adapter coupling. The operation of replacing the oxygen with nitrogen was repeated four times to ensure the required level of oxygen. After that the bag will be totally sealed and opened again at the end of those 14 days.

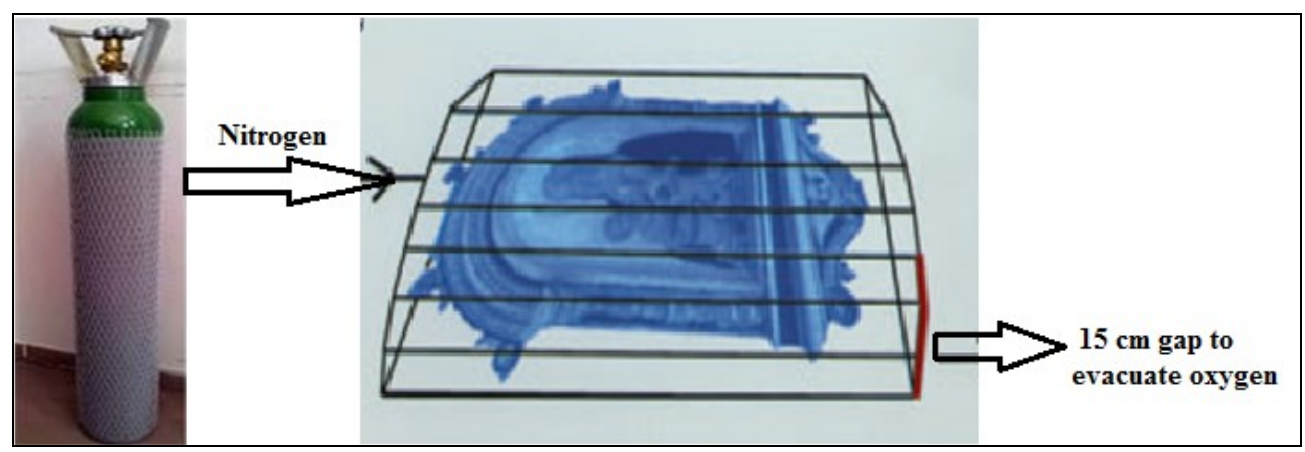

Fig. 23. The scheme of the criptoclimate

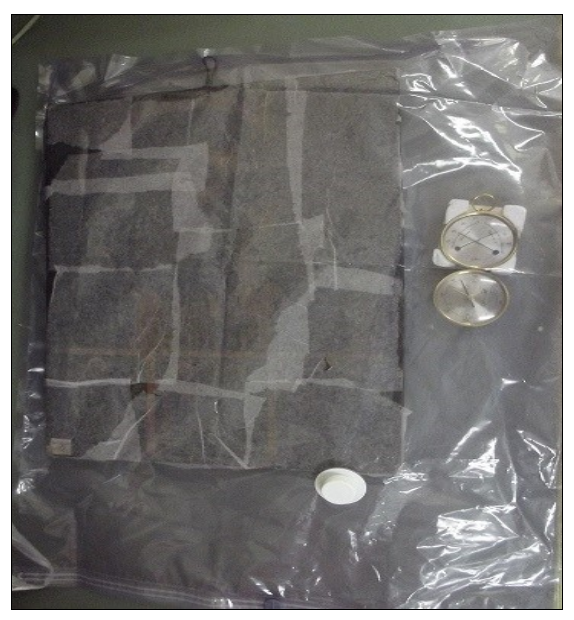

Fig. 24. Icon number 112 inside the criptoclimate

The next stage was to consolidate the two wooden panels with a mixture of colophony and natural bee wax, on a 1:1 ratio. The consolidation gave back the structural integrity that the two panels losed it as a consequence of the xylophagous attack (fig. 25) [17-19]. 


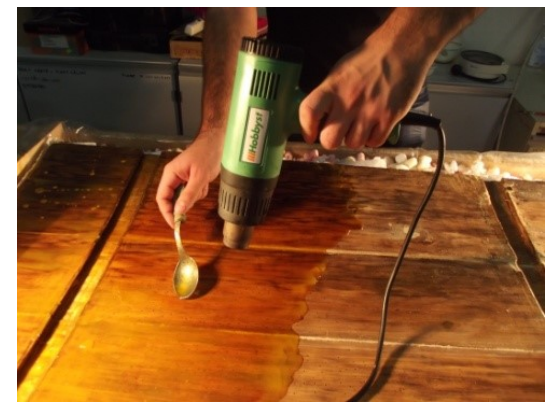

Fig. 25. Consolidating the wood support wiwax and colophony

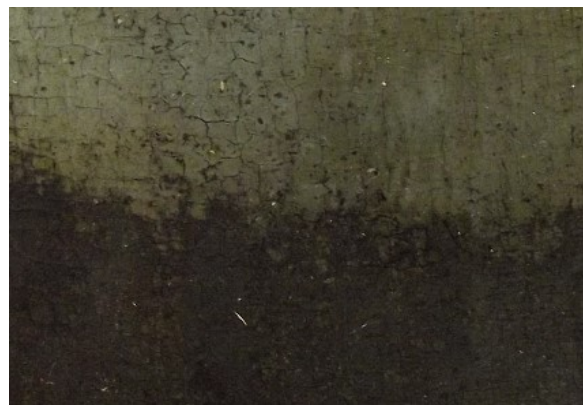

Fig. 26. Cleaning test of the icon number 112

After that the painting layers were cleaned with a solution of ethylic alcohol and distilled water (1:1). This solution had the best results in the cleaning test executed as shown in the figure 26. After the clogged dirt was cleaned and the aged varnish was removed, the gaps of the two icons were also cleaned and then filled with a mixture of animal glue (8\%) and charcoal. The filling will be applied in thin layers, with a window of a minimum 12 hours between applications, in order to ensure a proper exsiccation of the filled gaps. The filled gaps were sanded off and then reintegrated using tratteggio technique. The information obtained about the pigments used by the painters was taken into consideration in choosing the colors used for reintegration. Pigments with similar physical properties with those of the original colors were used.

After the gaps were reintegrated, the two icons were revarnished in order to ensure o proper protection against the future processes of deterioration and degradation that will affect the painting layers.

\section{Conclusions}

This study presented the stages of the restoration process of two XIX-th century icons, which are part of the cultural heritage of"Sfinții Mihail și Gavriil" from Moscu village, Galați. The icons suffer from a series of evaluative deteriorations and degradations processes, due to the improper storage environment. In order to reintegrate the two icons in the religious circuit, a restoration protocol was established and followed. A series of tests were employed, in order to determine the materials used by the painters, and then the established stages of the restoration protocol were followed: stopping the xylophagous attack by anaerobic treatment, consolidating the two wood panels and the painting layers, removing the clogged dirt and the degraded varnish, filling and sanding off the gaps, reintegration in tratteggio and varnishing the icons. For the chromatic 
reintegration pigments with similar properties like the properties of the original colors were used. The study present the stages of the restoration process of the two XIX-th icons, that were affected by being kept in an improper environment from a climatic point of view, and the results of the analysis done in order to collect information. MO, SEM-EDX and micro-FTIR were done on five samples collected from each icon. The following pigments were identified: natural ultramarine blue, earth green, carbon black, yellow iron oxide, lead white, burned and unburned umber. It was also established that colophon was used to protect the painting layer. In both cases, the gold leaf usually used in byzantine painting was replaced with silver leaf covered with varnish (icon number 112) or with yellow metallic pigments (realgar or orpigment). The restoration process that started after the analyses had the following stages: : consolidation of the painting layer (fish glue $8 \%$ and japanese paper), stopping the xylophagous attack (encapsulation with nitrogen), consolidation of the wood supports (colophon and wax, 1:1), cleaning the painting layer (ethylic alcohol and distilled water, 1:1), filling the gaps and reintegrating the fillings in tratteggio, all followed by the process of varnishing the two icons.

\section{References}

V. Lazarev, Icoane vechi românești, Ed. Meridiane, București, 2007

J.K. Atkinson, Environmental conditions for the safeguarding of collections: A background to the current debate on the control of relative humidity and temperature, Studies in Conservation, 59, (4), 2014, pp. 205-212.

S. Stanisforth, Environmental conditions for the safeguarding of collections: Future trends, Studies in Conservation, 59, (4), 2014, pp. 213-217.

C. Pereira, T. Busani, L.C. Branco, I. Joosten, I.C.A. Sandu, Nondestructive Characterization and Enzyme Cleaning of Painted Surfaces: Assessment from the Macro to Nano Level, Microscopy and Microanalysis, 19, (6), 2013, pp. 1632-1644.

I.C.A. Sandu, E. Murta, R. Veiga, V.S.F. Muralha, M. Pereira, S. Kuckova, T. Busani, An innovative, interdisciplinary, and multi-technique study of gilding and painting techniques in the decoration of the main altarpiece of Miranda do Douro Cathedral (XVII-XVIIIth centuries, Portugal), Microscopy Research and Technique, 76, (7),

I.C.A. Sandu, S. Schafer, D. Magrini, S. Bracci, C.A. Roque, Cross-Section and Staining-Based Techniques for Investigating Organic Materials in Painted and Polychrome Works of Art: A Review, Microscopy and Microanalysis, 18, (4), 2012, pp. 860-875.

J.A. Stratis, C. Makarona, D. Lazidou, E.G. Sanchez, A. Koutsoudis, M. Pamplona, R. Pauswein, G. Pavlidis, S. Simon, N. Tsirliganis, Enhancing the examination workflow for Byzantine icons: Implementation of information technology tools in a traditional context, Journal of Cultural Heritage, 15, (1), 2014, pp. 85-91.

S. Daniilia，D. Bikiaris， L. Burgio，P. Gavala，R.J.H. Clark，Y. Chryssoulakis，An 
extensive non-destructive and micro-spectroscopic study of two postByzantineoverpainted icons of the 16th century, Journal of Raman Spectroscopy, 33, (10), 2002, pp. 807-814.

J. Gancarczyk, Decision Tree Based Approach to Craquelure Identification in Old Paintings, Image Processing and Communications Challenges 4, Book Series: Advances in Intelligent Systems and Computing, Volume: 184, 2013, pp. 11 17.2013, pp. 733-743.

M. Munteanu, I. Sandu, V. Vasilache, A.M. Budu, I. C. A. Sandu, The study of the conservation of two icons, on wooden support, from the XIX ${ }^{\text {th }}$ century, Procedings of The 6th edition of EUROINVENT, European Exhibition of Creativity and Innovation, Alexandru Ioan Cuza UniverityPublishing House, p. 565

Z. Kaszowskaa, K. Malekb, M. Pan'czykc, A. Mikołajskaa, $A$ joint application of ATRFTIR and SEM imaging with high spatial resolution: Identification and distribution of painting materials and their degradation products in paint cross sections, Vib. Spectrosc., 65, 2013, pp. 1- 11

A.P. Laurie, Methods of Testing Minute Quantities of Materials from Pictures and Works of Art, The Analyst, LVIII, 1933, p.468

R.A. Cristache, I. Sandu, V. Vasilache, O. Cristache, Study of Archeometric Characteristics of a Panel Painted Icon Form XIXth Century, Acta Chemica Iasi, 212, 71-82, 2013, pp. 71-82

M.T. Domenech Carbo, F. Bosch Reig, J.V. Gimeno Adelantado, V. Periz Martinez, Fourier transform infrared spectroscopy and the analytical study of works of art for purposes of diagnosis and conservation, Anal. Chim. Acta, 330, 1996, pp. 207-215.

C. Genestar, C. Pons, Earth pigments in painting: Characterization and differentiation by means of FTIR spectroscopy and SEM- EDS microanalysis, Anal. Bioanal. Chem., 382, 2005, pp. 269-274.

I. Sandu, Identificarea materialelor picturale, Ed. Performantica, Iași, 2007.

I.C.A. Sandu, M. Helena de Sa, M. Costa Pereira, Ancient 'gilded' art objects from European cultural heritage: A review on different scales of characterization, Surface and Interface Analysis, 43, (8), 2010, pp. 1134-1151.

O. Katsibiri, B. Singer, J. Devenport, Some aspectes of the technique and materials used for mordant gilding on byxantine icons and wall painting, Art2002, 7th International Conference for Non-destructive Testing and Microanalysis for the Diagnostic and Conservation of the Cultural and Environmental Heritage, Antwerp, June, 2002

R.A. Blanchette, A Guide to Wood Deterioration Caused by Microorganisms and Insects, The Structural Conservation of Panel Paintings. Procedings of a Symposium at the J. Paul Getty Museum, april 1995, p. 55 